\title{
Individuals, families and neighbourhoods: social resources and educational attainment
}

Citation for published version (APA):

Bosker, R. J., \& van der Velden, R. K. W. (1992). Individuals, families and neighbourhoods: social resources and educational attainment. Researchcentrum voor Onderwijs en Arbeidsmarkt, Faculteit der Economische Wetenschappen. ROA Research Memoranda No. 7E https://doi.org/10.26481/umaror.199207E

Document status and date:

Published: 01/01/1992

DOI:

10.26481/umaror.199207E

Document Version:

Publisher's PDF, also known as Version of record

\section{Please check the document version of this publication:}

- A submitted manuscript is the version of the article upon submission and before peer-review. There can be important differences between the submitted version and the official published version of record.

People interested in the research are advised to contact the author for the final version of the publication, or visit the DOI to the publisher's website.

- The final author version and the galley proof are versions of the publication after peer review.

- The final published version features the final layout of the paper including the volume, issue and page numbers.

Link to publication

\footnotetext{
General rights rights.

- You may freely distribute the URL identifying the publication in the public portal. please follow below link for the End User Agreement:

www.umlib.nl/taverne-license

Take down policy

If you believe that this document breaches copyright please contact us at:

repository@maastrichtuniversity.nl

providing details and we will investigate your claim.
}

Copyright and moral rights for the publications made accessible in the public portal are retained by the authors and/or other copyright owners and it is a condition of accessing publications that users recognise and abide by the legal requirements associated with these

- Users may download and print one copy of any publication from the public portal for the purpose of private study or research.

- You may not further distribute the material or use it for any profit-making activity or commercial gain

If the publication is distributed under the terms of Article $25 \mathrm{fa}$ of the Dutch Copyright Act, indicated by the "Taverne" license above, 
INDIVIDUALS, FAMILIES AND NEIGHBOURHOODS:

SOCIAL RESOURCES AND EDUCATIONAL

ATTAINMENT

ROA-RM-1992/7E

R.J. Bosker and R.K.W. van der Velden

RESEARCH CENTRE FOR EDUCATION AND THE LABOUR MARKET

Rijksuniversiteit Limburg

Faculty of Economics and Business Administration

Maastricht, December 1992 


\section{CIP-GEGEVENS KONINKLIJKE BIBLIOTHEEK, DEN HAAG}

Bosker, R.J.

Individuals, families and neighbourhoods: social resources and educational attainment / R.J. Bosker and R.K.W. van der Velden. - Maastricht : Research Centre for Education and the Labour Market, Rijksuniversiteit Limburg, Faculty of Economics and Business Administration. - III. (ROA-RM-1992/7E)

Met lit. opg.

ISBN 90-5321-095-4 in spiraalband Trefw.: onderwijs en sociaal milieu. 
CONTENTS

Page

ABSTRACT

i

1. INTRODUCTION

2. DATA 3

3. STATISTICAL MODELLING ISSUES 5

4. RESULTS 8

5. CONCLUSION 16

$\begin{array}{ll}\text { REFERENCES } & 18\end{array}$

APPENDIX. DESCRIPTION OF VARIABLES 22 


\section{ABSTRACT}

This article explores the effects of social resources on educational attainment. By using multilevel techniques the relative importance of individual, family and neighbourhood factors are estimated, and consequently predicted, using several variables. The total effect of family and neighbourhood on educational attainment amounts to 50 percent, the social status of the parents being the most important predictor. The social resources available to a family, however, do play a role, especially the family's access to social networks, the openness of the network, and the social status of the network or neighbourhood. The standardized effects of the various social resources are comparable to the standardized effect of the occupational prestige of the father. Moreover, the study provides an explanation of why children from families living in deprived neighbourhoods have less educational opportunities than children from families living in privileged areas: their families are more likely to have a low status network of limited range. 


\section{INTRODUCTION}

In the sociology of education, an extensive empirical tradition has developed on the social determinants of educational attainment (for an overview see Hallinan 1988; Dronkers 1990). The effect of the socio-economic status of the family of origin, as indicated by the occupation of the father and educational background of both parents, has been an important focus. Cultural resources in particular seem to mediate these status effects (Collins 1979; Bourdieu 1984; De Graaf 1986).

This article ${ }^{1}$ addresses itself not to the effects of the cultural resources of the family, but to the effects of its social resources. Social resources refer to the effects of the social network of the family, such as friends, relatives, or the neighbourhood in which the family lives. Two questions are central:

1. What is the total amount of environmental effects on the educational attainment of individuals?

2. What are the effects of social resources on educational attainment?

Literature on the effects of social resources stems from three different lines of research. First, there is a long tradition of research on neighbourhood effects (Hummel 1972), which has shown a revival in recent years with the study of the 'ghetto poor'. In his 1990 Presidential Address, Wilson calls the study of inner-city dislocations a major challenge for future research (Wilson 1991). According to him "the effects of living in a neighbourhood that is overwhelmingly impoverished (...) are created by the constraints and opportunities that the residents of the inner-city neighbourhoods face in terms of access to jobs and job networks, involvement in quality schools, availability of marriageable partners, and exposure to conventional role models" (Wilson 1991, p.11). Although this line of studies is mainly focused on the effects of extreme neighbourhood deprivation, general neighbourhood effects have also been demonstrated (Dronkers and Diekerhof 1984; Dronkers and Schijf 1986). In a recent study, Garner and Raudenbush (1991) showed that the total neighbourhood effect amounts to 3 percent of the variance in educational attainment, after controlling for individual and family characteristics.

The second line of research regards the effect of social resources on the labour market career (Granovetter 1973). On the one hand it stresses the importance of access to relevant social networks. People who are denied such access (e.g. because they are unemployed), experience more difficulties in finding a good job (Tazelaar and Sprengers 1984). On the other hand the quality of the network itself is stressed. Social networks seem particularly effective if the social status of the persons who belong to the network is high (Ganzeboom 1988; De Graaf and Flap

1. An earlier version of this paper was presented at the XIlth World Congress of Sociology in Madrid, and the Columbus meeting of the ISA Research Committee on Social Stratification and Mobility. The research was carried out at the Institute for Educational Research (RION) in Groningen, with a grant form SVO (SVO-project 4229). We thank Jaap Dronkers, Andries de Grip, Robert M. Hauser, James Hsueh and Stephen W. Raudenbush for their comments on earlier versions. 
1988). Furthermore the effectiveness of a network depends not so much on the so-called 'strong' relations (i.e., family and relatives), but rather on the 'weak' relations: the weak-tie effect (Lin, Ensel and Vaughn 1981).

This is in accordance with findings from family socialization research, where a closed network which is limited to the immediate family is found to have negative effects. Neidhartdt (1970) associates these networks with 'disfunktionale Schmallspursozialisation', where emphasis is put on the development of particularistic values. This limits the problem-solving capacity of the family as a social system. In higher status groups the networks of the families usually have a more open character. The relations are less interwoven and the networks are not limited to the immediate family. This promotes the development of universalistic values and has a positive effect on the children's educational attainment. 


\section{DATA}

In 1972 the Sociological Department of the University of Groningen in the Netherlands started a longitudinal study to examine the effects of social background on intellectual development and to determine the family characteristics which mediate this environmental effect (Meijnen 1977). Later, the study was extended to the effects of schools on educational attainment and cognitive development during primary education (Meijnen 1984). In 1984 the Institute for Educational Research (RION) again approached the original cohort of 728 pupils to assess their career in secondary education. In that study the pupils themselves, their parents and the teachers of the schools the children attended were interviewed (Bosker, Hofman, and Van der Velden 1985; Bosker, Van der Velden, and Otten 1989; Bosker and Van der Velden 1989). An experimental loss of $22 \%$ of the 1972 sample was suffered, due to non-response and unavailability. Moreover, pupils who had been referred to special education were interviewed in a different way, so complete information could be obtained for only 519 of the original 728 families. This loss did not, however, affect the representativeness of the sample.

The variables that have been selected for the analysis to be performed here relate to three different levels:

1. Characteristics of the children in the family, i.e. the pupils from the cohort and their siblings;

2. Family characteristics;

3. Characteristics of the neighbourhood the families live in.

In the survey the mother was asked to give the following information for all of her children: sex, birth order and educational attainment at that moment. Here, however, a problem arises. In most cases the elder children of the family have already completed their educational career: for them the attained level can easily be assessed. This is not true for the younger ones: sometimes they are still in secondary education, a number of them still attend primary school. To overcome this problem, a transformation was applied to the variable educational attainment, which assessed the level of secondary education for each child of the family. In the Dutch educational system pupils choose at the age of twelve which type of education they will follow. The following main forms can be distinguished, ranging in decreasing order of difficulty:

1. VWO : pre-university education, duration 6 years.

2. HAVO: higher general education, duration 5 years.

3. MAVO: intermediate general education, duration 4 years.

4. LBO : junior vocational education, duration 4 years.

5. IBO: individual vocational education, duration 4 years.

These five streams might be interpreted as curriculum tracks, with little mobility between them except for graduate pupils (LBO certificate gives access to MAVO grade 4 and so on). The educational attainment was transformed into one of these five tracks (see appendix). This variable, the 'level of secondary education', serves as the dependent variable.

Children who are still in primary education were left out of the analysis, as were those for whom information on one of the individual variables sex, birth order or level of secondary 
education was not available. In sum the 519 families contained 1,478 children (the cohort children included). Of these, 121 were excluded, mainly because they were younger than 12 years. So 1,357 children, in 516 families, remained.

The following socio-structural characteristics of these families have been taken into account in the analysis: occupational prestige of the father, educational attainment of the father, educational attainment of the mother, unemployment of the father, social participation of the mother, the number of children in the family, one-parent family, the social network of the family, occupational prestige of the grandfather and the average occupational prestige of acquaintances (see appendix for a description of the variables).

The neighbourhood where these families lived in 1972, the year in which the cohort was selected, was determined. The 516 families lived in 42 neighbourhoods. These neighbourhoods were grouped according to the CBS (Central Bureau for Statistics) system of neighbourhood classification (CBS 1981), which makes it possible to assign a score for 'social deprivation' to each neighbourhood. These scores are derived from the Social and Cultural Planning Office (SCP 1980), who has carried out a factor analysis based on a number of neighbourhood social indicators, using the census of 1971 . These indicators are aggregated data at neighbourhood level about occupational level, educational attainment, income, quality of housing and the consumption of luxury goods (SCP 1980). The resulting factor scores indicate the social deprivation of each neighbourhood. The obtained factor scores have been standardized on mean 0 and standard deviation 1. A positive factor score means a large social deprivation, a negative score indicates little deprivation. By way of illustration: the factor scores of the 42 neighbourhoods in the Groningen cohort range from -3.28 for the district Coendersborg to +1.86 for the district Damsterdiep and surroundings. 


\section{STATISTICAL MODELLING ISSUES}

The determination of the total influence of the family and its surrounds requires that the total variance in educational attainment must be broken down into variance within families, variance between families and variance between environments. Research into the overall effect of the family on children's attainment, aptly described by Dronkers (1989) as "the power of the family", has a long tradition. One used to assess this family effect by considering the educational attainment of both the respondent and the respondent's brother (Olneck 1977). With the introduction of a structural causal model by Benin and Johnson (1984) it became possible for the first time to assess the measured as well as the unmeasured family effects. Since that time various so-called sibling models have been developed in the field (Hauser and Mossel 1985; Hauser and Sewell 1985; Hauser and Sewell 1986; Hauser and Wong 1989). The empirical results obtained with these sibling models suggest that about 50 to $60 \%$ of the variance in educational attainment can be ascribed to the family factor and that $50 \%$ of this family factor, in turn, is determined by social status variables (De Graaf and Huinink 1991).

The use of these sibling models has a number of advantages. In the first place, the use of a linear-structural model allows the total measured and unmeasured influence of the family to be accounted for. This is defined as the common variation in the educational level achieved by the children of one family (strictly speaking, the common variation in the educational level achieved by older and younger siblings). In the second place, LISREL offers the possibility of specifying both a measurement model and a structural model.

The model, however, also has a number of disadvantages. Multiple individual variables can be included in the model, but this rapidly leads to a very complex model, such as the use of multiple latent family factors (c.f. Hauser and Sewell 1986). Moreover the model does not do justice to the multi-level character of the data. The multi-level problem is avoided in the sibling model by using the educational attainment of the children as an indicator of the 'family effect', which apparently results in a single-level analysis. That does not rule out the fact that two or even three levels can be distinguished: the level of the individual children in the family, the level of the family, and the level of the family's environment.

Alternative statistical techniques, known as hierarchical models, are available for the study of the family effect (Goldstein 1987). These have mainly been developed in school effectiveness research focused on a comparable multi-level question: "What are the effects of schools on pupils' attainment?" The techniques concerned were especially developed to cope with the statistical problems, such as the mutual dependency of the residuals, that occur in the analysis of multi-level data. The technique bears a strong resemblance to the analysis of covariance. Context effects are regarded as the effects of a random factor. Thus one can first examine what part of the variance reflects systematic variance between contexts. Unlike the analysis of covariance, this is a matter of 'true' parameter variance, which means that the estimation of the variance component is corrected for sample fluctuations. Next, a regression model is estimated at the individual level, in which, however, the regression of the criterion variable on 
the predictors may vary between contexts. In this way a model is created in which the effect of a predictor is context dependent: in this case the effect is random. If there is no variance in the parameters between contexts, it is called a fixed effect. Finally an explanation of the estimated variance in these intercepts and slopes can be attempted, using context variables.

For the present analysis we make use of the random coefficient model, a model apt for analyzing hierarchically structured data (c.f. Aitkin and Longford 1986; Raudenbush and Bryk 1986). This model can be formulated as (underlined symbols indicate random variables):

(1) $\underline{\underline{y}}_{\mathrm{ijk}}=\underline{B}_{0 \mathrm{jk}}+\underline{B}_{1 \mathrm{jk}} x_{\mathrm{ijk}}+\underline{\mathrm{e}}_{\mathrm{jik}}$

in which

$\bigvee_{i j k}:$ the score on the dependent variable for child $i$ in family $j$ in neighbourhood $k$;

$\underline{B}_{0 j k}$ : the mean score for family $j$ in neighbourhood $k$;

$\underline{B}_{1 \mathrm{jk}}$ : the family specific coefficient for the regression of $y$ on $x$;

$x_{i j k}$ : a predictor variable at the child level;

$\underline{e}_{\mathrm{ijk}}$ : the child level residual with variance $\sigma_{\mathrm{e}}^{2}$.

Furthermore

(2) $\underline{B}_{0 \mathrm{jk}}=\underline{B}_{00 \mathrm{k}}+\underline{u}_{\mathrm{jjk}}$

in which

$\underline{B}_{0 o k}:$ the mean score of neighbourhood $k$;

$\underline{\mathrm{u}}_{\mathrm{j} \mathrm{jk}}:$ the family level residual with variance $\sigma_{\mathrm{uo}}^{2}$.

and of course

(3) $\underline{B}_{00 k}=B_{000}+\underline{V}_{00 k}$

in which

$\underline{B}_{000}:$ the mean score or grand mean;

$\underline{\mathrm{v}}_{\mathrm{ook}}$ : the neighbourhood level residual with variance $\sigma_{\mathrm{vo}}^{2}$.

An important aspect of this set of equations is that the multi-stage sampling scheme is adequately modelled at all three levels, and that the residuals are uncorrelated between but not within levels. Children from two different families and from two different neighbourhoods have nothing in common, but the residuals for two children $i$ and $i^{\prime}$ from one and the same family are correlated as 
(4) $\operatorname{cov}\left(y_{i j k}, y_{i j k}\right)=\sigma_{u o}^{2}+\sigma_{v o}^{2}$

Whereas the residuals of two families from two different neighbourhoods are correlated as

(5) $\operatorname{cov}\left(y_{i j k}, Y_{i^{\prime} j^{\prime} k}\right)=\sigma_{v o}^{2}$

Analogous to (2) and (3) we can formulate models for family and neighbourhood specific residuals and variances for the random coefficient $\beta_{1 \mathrm{j} k}$. In this case we have the family level residual for the regression coefficient $\beta_{1}, \underline{u}_{1 j k}$, with variance $\sigma_{u 1}^{2}$ and the neighbourhood residual $\underline{v}_{10 k}$, with variance $\sigma_{v 1}^{2}$. The expressions for $(4)$ and (5), however, become somewhat more complicated, although the logic remains the same.

Multi-level analysis has a number of advantages over the sibling model discussed above. First, it takes proper account, in statistical terms, of the hierarchical structure of the data. Second, it allows one to include random effects in the model. Third, the model has a simple structure, especially when several independent variables have to be taken into account. On the other hand, it has the disadvantage of not allowing the modelling of measurement errors or the causal structure.

In this article the VARCL-package (Longford 1986) will be used to perform a multi-level analysis on the Groningen cohort to assess the total family effect on educational careers and to explore the effects of social resources. Three levels will be distinguished: the child, the family and the neighbourhood. The total family effect is defined, as in the sibling model, as the common variance in the educational attainment of the children of one family, also called the inter-family variance. It should be noted that a portion of the family effect will be underestimated with this method, since the pattern of interaction between parents and their children can vary from child to child, and this interaction has an effect on their educational attainment. The same is true for the influences of the broader social environment. In so far as these are not identical for every child in the family (the influence of teachers and of friends, for instance), they will be subsumed under individual or intra-family variance. In other words, environmental influences may be registered as variances within the family. In contrast to sibling analysis, multi-level analysis allows such family-individual interactions to be detected, for example when the effect of individual characteristics on attainment varies from family to family. The sibling model does not show these effects. The absence of a fixed effect and the simultaneous appearance of a random effect of e.g. birth-order shows that in some families the first child achieves the highest educational level, and in others the last. Unlike the total family effect, these family-individual interactions can only be demonstrated for measured individual variables.

As far as we know, such a three level analysis, with the level of secondary education as the dependent variable, has not been performed before. Garner and Raudenbusch (1991) distinguish individuals and neighbourhoods as levels of analysis (and take the school into consideration as a separate factor). However, since they do not include the family as a separate level, they are not able to assess the total family effect. 


\section{RESULTS}

Before showing the results, it is necessary to consider whether it is useful to consider the neighbourhood as a separate level. Problems may occur in assessing neighbourhood effects if there are few observations (in this case, few families) per neighbourhood. Table 1 shows that this is the case to a certain extent.

Table 1. Number of families per neighbourhood

$\begin{array}{lllr}\text { Number of neighbourhoods with } & 1 & \text { family: } & 9 \\ \text { Number of neighbourhoods with } & 2-5 & \text { families: } & 5 \\ \text { Number of neighbourhoods with } & 6-10 & \text { families: } & 13 \\ \text { Number of neighbourhoods with } & 11-20 & \text { families: } & 8 \\ \text { Number of neighbourhoods with } & >20 & \text { families: } & 7 \\ & & & -- \\ \text { Total: } & & & 42\end{array}$

In one out of five neighbourhoods there is just one family. In most neighbourhoods there are few families. This does not cause real problems for the analysis, since the contribution of specific neighbourhoods to the estimation of neighbourhood effects is weighted by the reliability of the information from these neighbourhoods, a.o. the number of families observed (c.f. Raudenbush and Bryk 1986). A serious problem may arise, however, if the neighbourhoods are highly homogeneous in family characteristics. If, for example, there is very little variance in occupational prestige within a neighbourhood, family and neighbourhood effects cannot be meaningfully separated. Table 2 shows the amount of variance for a number of family variables between neighbourhoods and within neighbourhoods. The homogeneity of the neighbourhood can be expressed as the within-neighbourhoods between-families correlation:

(6) $\rho=\sigma_{\mathrm{vo}}^{2} /\left(\sigma_{\mathrm{uo}}^{2}+\sigma_{\mathrm{vo}}^{2}\right)$

Table 2. Variance in family characteristics

$\begin{array}{lll}\text { family characteristic } & \begin{array}{l}\text { within neigh- } \\ \text { bourhoods }\end{array} & \begin{array}{l}\text { between neigh- } \\ \text { bourhoods }\end{array}\end{array}$

\begin{tabular}{lrrr}
\hline occ. prestige father & 1.79 & .70 & .28 \\
educ. attainm. father & 1.67 & .70 & .30 \\
educ. attainm. mother & 1.42 & .34 & .19 \\
number of children & .68 & .04 & .06 \\
occ. prest. acquaintances & 2.08 & .17 & .08 \\
occ. prest. grandfather & 1.81 & .26 & .13
\end{tabular}

The table shows that there is a considerable heterogeneity within neighbourhoods: for most family characteristics the variance between neighbourhoods is small compared to the variance within a neighbourhood. Although the sensitivity of the model to neighbourhood effects will be diminished to some extent, it is, in principal, possible to distinguish neighbourhood from family effects without serious difficulties. 
In the VARCL analysis six models will be analyzed, beginning with models in which only lowlevel variables are specified, and ending with models in which both low and high level variables are taken into account. The reason for this is that under-specification of the individual level can lead to an overestimate of the environmental effect. The neighbourhood effect, for instance, could be entirely a product of the aggregated effects of the families who live in a neighbourhood. Without controlling for the social status of parents, for example, the neighbourhood effect would be greatly overestimated (c.f. Hauser 1970). Therefore before looking for possible neighbourhood effects, it is sensible to specify as many variables as possible on the lower (individual and family) levels.

In model 0 an overall constant will be fitted on the data. On the basis of estimates of the various components of variance (respectively the individual, family and neighbourhood) a calculation can be made of how much variance in the level of secondary education should be ascribed to systematic differences between families or neighbourhoods and what part of the variance is purely individual or can be ascribed to sample fluctuations.

In model 1 the effects of the individual characteristics of the children in a family are examined, in order to specify the lowest level as well as possible. In fact a good deal was known about the students in the cohort, but for the other children in the families the only information available was their sex and birth order. The effect of sex on educational attainment has undergone a change over the years (Bakker and Schouten 1991). Girls used to perform worse than boys, whereas nowadays they perform slightly better, at least at the transition from primary to secondary education. The effect of birth order is usually explained in terms of the 'confluence model' of Zajonc and Markus (1975): the elder children perform better than the younger ones, because the former serve, to some extent, as teachers for the latter.

In model 2 the socio-economic status of the family is introduced ${ }^{2}$ : besides the occupational prestige of the father the educational attainment of both parents is included. Empirical research shows that the latter variable in particular is a good predictor of the children's school success (Dronkers 1990; De Graaf 1989).

Model 3 introduces the variables which describe the family's access to relevant social networks. The first of these is the unemployment of the father. Being out of work means the loss of an important part of the family's contacts: not just work contacts but also a portion of its general social contacts (Tazelaar and Springers 1984). Long-term unemployment in particular can lead to social isolation and the loss of social capital, but even short-term unemployment can be an indicator of the social network available to the family. Employment uncertainties are most evident in occupations of the so-called secondary segment (Doeringer and Piore 1971), i.e, the portion of the labour market occupied mainly by those with poor education and others with a weak position in the market. This is not the sector in which people with influential contacts are

2. Due to underrepresentation in the Groningen cohort, no variable referring to the ethnic background of the parents is included in the analysis. 
to be found. In the Netherlands the effect of unemployment on educational attainment has been examined by Te Grotenhuis and Dronkers (1989). They found a negative effect, after controlling for other factors.

Access to the relevant social networks is also often restricted for single-parent families. The effects of divorce or the death of one of the parents on educational attainment have been extensively studied by Bosman and Louwes (1988; 1989), who found negative effects, in particular resulting from divorce.

The establishment of a network through the work-place is often out of the question for mothers, since they usually do not have paid jobs. The mother was therefore asked what clubs and organizations she was a member of, and how actively involved she was. On the basis of this information two variables were developed. The diversity of social participation measures to what extent the mother participates in different sorts of organizations. The second variable reflects how actively involved she is in these organizations. Both variables have been supposed to have a positive effect on the type of secondary education chosen.

Hauser and Sewell (1985) have shown that the effect of birth order largely disappears, as soon as the total number of children in a family has been controlled for (in large families the average educational attainment is lower than in smaller ones). In model 3, therefore, the number of children is included as a predictor variable.

Model 4 introduces variables that refer to the social network itself. The network variable is a fairly rough measure that indicates whether the social network of the family, the people they contact, is limited to family or neighbours or whether it is more extensive. A limited network is evidence of what Neidhardt (1970) calls 'dysfunktionale Schmallspursozialisation'. Such a network is typical of lower status groups (Huckfeldt 1983) and probably has a negative effect on educational attainment (Ganzeboom 1988). The significance of the network for the family is strongly determined by the social status of the persons belonging to the network. In our study information was gathered on the social background of the mothers ${ }^{3}$, as well as on the average occupational level of the persons the parents contact most frequently. Both variables are expected to have a positive effect on the educational attainment of children.

Model 5 introduces the social deprivation score of the neighbourhood. Given the coding method (the higher the score, the larger the deprivation), a negative effect on the level of secondary education achieved is expected.

Finally, model 6 investigates the possibility of suppressor effects for two variables. The variables social network and social status of the persons belonging to this network are, strictly speaking, not family level variables. These variables are between the neighbourhood and the family level. What may happen is, that these variables, being collinear with the social

3. Corresponding information about the social background of the fathers was not collected. 
deprivation variable, already account for variance that may actually also be ascribed to the social deprivation of the neighbourhood. In other words, families living in deprived neighbourhoods are more likely to participate in narrow ranged, low status networks. Model 6 tests this hypothesis by deleting the two network variables from the model to be fitted to the data.

Table 3 contains the outcomes of the analysis. The upper part of the table contains the fixed effects estimates, that can be readily interpreted as regression coefficients. The middle part of the table contains information about the random part of the model, i.e. the variance components. These are the estimates of unique within family variance, unique between family variance, and unique between-neighbourhood variance in the population. Moreover a section is included on the variance that is accounted for at the three levels by the predictor variables in the model. The last section of the table contains goodness of fit information (the DEVIANCE is $-2 *$ log-likelihood), and the improvement of the goodness of fit by including new predictor variables (differences in DEVIANCES are $x^{2}$-distributed with as many degrees of freedom loss as the number of new parameters to be estimated in the more complex model).

Model $O$ shows that the average level of secondary education is 3.37, which is slightly higher than MAVO (lower general secondary education). Below the table stand the estimates of the various components of the variance, using model 0 . The estimation of the variance components follows a hierarchical order. First the systematic variance between neighbourhoods is estimated, and then the systematic inter-family variance. What remains is the actual variance within the family and the random variance (measurement error and sampling variance). Almost half the variance in the dependent variable 'level of secondary education' has to be ascribed to systematic differences between families $(35 \%)$ or between neighbourhoods $113 \%)$. The remaining variance concerns differences between individuals within families. To put this more precisely, the level of secondary education a student chooses is approximately $50 \%$ determined by the systematic influence from the environment which he shares with his brothers and sisters. This environmental influence includes e.g. the genetic inheritance and child-rearing methods which they have in common, but also the wider environment in which they live.

This estimation of the context variance (48\%) corresponds well to the results of analyses using sibling models. Hauser and Wong (1989) mention research showing that half to two thirds of the variance in educational attainment can be ascribed to a common family factor. That this percentage is somewhat higher than the $48 \%$ found with the VARCL analysis, has to do with the fact that the Hauser-Wong model takes into account measurement errors in the assessment of educational attainment ${ }^{4}$.

4. Application of the Hauser-Wong model to our data produces an estimate of the common factor of $56 \%$, which is indeed higher than the $48 \%$ found in the VARCL-analysis. 
Table 3. Multi-level analysis of social determinants of educational attainment: parameter estimates and model fit (the first number refers to the unstandardized effects, the second to the standardized effects; standard errors between brackets)

\begin{tabular}{|c|c|c|c|c|c|c|c|}
\hline Variable & model 0 & model 1 & model 2 & model 3 & model 4 & model 5 & model 6 \\
\hline Constant: & $\begin{array}{l}3.37 \\
(.09)\end{array}$ & $\begin{array}{l}3.59 \\
(.09)\end{array}$ & $\begin{array}{l}1.91 \\
(.04)\end{array}$ & $\begin{array}{l}1.97 \\
(.03)\end{array}$ & $\begin{array}{l}1.70 \\
(.03)\end{array}$ & $\begin{array}{l}1.79 \\
(.03)\end{array}$ & $\begin{array}{l}2.06 \\
(.03)\end{array}$ \\
\hline $\begin{array}{l}\text { Individual: } \\
\text { birth order }\end{array}$ & & $\begin{array}{l}-.09 /-.10 \\
(.02)\end{array}$ & $\begin{array}{l}-.08 /-.09 \\
(.02)\end{array}$ & $\begin{array}{l}-.06 /-.07 \\
(.02)\end{array}$ & $\begin{array}{l}-.06 /-.07 \\
(.02)\end{array}$ & $\begin{array}{l}-.06 /-.07 \\
(.02)\end{array}$ & $\begin{array}{l}-.06 /-.07 \\
(.02)\end{array}$ \\
\hline fixed sex-effect & & $\begin{array}{l}-.11 /-.05 * \\
(.06)\end{array}$ & $\begin{array}{l}-.10 /-.04 * \\
(.05)\end{array}$ & $\begin{array}{l}-.10 /-.04 * \\
(.05)\end{array}$ & $\begin{array}{l}-.11 /-.05 \\
(.05)\end{array}$ & $\begin{array}{l}-.11 /-.05 \\
(.05)\end{array}$ & $\begin{array}{l}-.11 /-.05 \\
(.05)\end{array}$ \\
\hline $\begin{array}{l}\text { Family: } \\
\text { education father }\end{array}$ & & & $\begin{array}{l}.21 / .26 \\
(.03)\end{array}$ & $\begin{array}{l}.19 / .24 \\
(.03)\end{array}$ & $\begin{array}{l}.17 / .21 \\
(.03)\end{array}$ & $\begin{array}{l}.16 / .20 \\
(.03)\end{array}$ & $\begin{array}{l}.17 / .21 \\
(.03)\end{array}$ \\
\hline education mother & & & $\begin{array}{l}.20 / .22 \\
(.03)\end{array}$ & $\begin{array}{l}.21 / .23 \\
(.03)\end{array}$ & $\begin{array}{l}.19 / .21 \\
(.03)\end{array}$ & $\begin{array}{l}(18 / .19 \\
(.03)\end{array}$ & $\begin{array}{l}.20 / .22 \\
(.03)\end{array}$ \\
\hline occupation father & & & $\begin{array}{l}.10 / .13 \\
(.03)^{-13}\end{array}$ & $\begin{array}{l}.09 / .12 \\
(.03)\end{array}$ & $\begin{array}{l}.07 / .09 \\
(.03)\end{array}$ & $\begin{array}{l}.06 / .08 \\
(.03)\end{array}$ & $\begin{array}{l}.08 / .09 \\
(.03)\end{array}$ \\
\hline number of children & & & & $\begin{array}{l}-.05 /-.05 \\
(.02)\end{array}$ & $\begin{array}{l}-.05 /-.05^{*} \\
(.02)\end{array}$ & $\begin{array}{l}-.04 /-.04 * \\
(.02)\end{array}$ & $\begin{array}{l}-.05 /-.05 \\
(.02)\end{array}$ \\
\hline working father & & & & $\begin{array}{l}.21 / .07 \\
(.08)\end{array}$ & $\begin{array}{l}.20 / .07 \\
(.08)\end{array}$ & $\begin{array}{l}.21 / .07 \\
(.08)\end{array}$ & $\begin{array}{l}.221 .08 \\
(.08)\end{array}$ \\
\hline one-parent family & & & & $\begin{array}{l}-.39 /-.12 \\
(.08)\end{array}$ & $\begin{array}{l}-.38 /-.12 \\
(.08)\end{array}$ & $\begin{array}{l}-.38 /-.12 \\
(.08)\end{array}$ & $\begin{array}{l}-.38 /-.12 \\
(.08)\end{array}$ \\
\hline social network & & & & & $\begin{array}{l}.19 / .07 \\
(.07)\end{array}$ & $\begin{array}{l}.17 / .06 \\
(.07)\end{array}$ & \\
\hline occupation acquaintances & & & & & $\begin{array}{l}.07 / .09 \\
(.02)\end{array}$ & $\begin{array}{l}.07 / .09 \\
(.02)\end{array}$ & \\
\hline $\begin{array}{l}\text { Neighbourhood: } \\
\text { social disadvantage }\end{array}$ & & & & & & $\begin{array}{l}-.09 /-.08 \\
(.04)\end{array}$ & $\begin{array}{l}-.10 /-.09 \\
(.03)\end{array}$ \\
\hline $\begin{array}{l}\text { Variance components: } \\
\text { individual } \\
\left(\sigma_{\theta}^{2}\right)\end{array}$ & .741 & .695 & .689 & .695 & .693 & .692 & .695 \\
\hline $\begin{array}{l}\text { family } \\
\left(\sigma_{u 0}^{2}\right)\end{array}$ & .506 & .480 & .253 & .219 & .199 & .195 & .210 \\
\hline$\underset{\left(\sigma_{u 1}^{2}\right)}{\text { family }}$ * sex & & .166 & .169 & .151 & .161 & .165 & .156 \\
\hline $\begin{array}{l}\text { neighbourhood } \\
\left(\sigma_{v 0}^{2}\right)\end{array}$ & .182 & .186 & .003 & .000 & .003 & .000 & .000 \\
\hline $\begin{array}{l}\text { Total variance: } \\
\text { individual ** }\end{array}$ & $52 \%$ & $\begin{array}{l}\% \text { Modelled } \\
6 \%\end{array}$ & $\begin{array}{l}\text { variance } \\
7 \%\end{array}$ & $6 \%$ & $6 \%$ & $6 \%$ & $6 \%$ \\
\hline family & $35 \%$ & $5 \%$ & $50 \%$ & $57 \%$ & $61 \%$ & $61 \%$ & $58 \%$ \\
\hline neighbourhood & $13 \%$ & $0 \%$ & $98 \%$ & $100 \%$ & $98 \% * * *$ & $100 \%$ & $100 \%$ \\
\hline $\begin{array}{l}\text { Modelfit: } \\
\text { Deviance } \\
x^{2}\end{array}$ & 3999 & $\begin{array}{l}3965 \\
34\end{array}$ & $\begin{array}{l}3735 \\
230\end{array}$ & $\begin{array}{l}3705 \\
30\end{array}$ & $\begin{array}{l}3688 \\
17\end{array}$ & $\begin{array}{l}3682 \\
6\end{array}$ & $\begin{array}{l}3696 \\
9 * * * *\end{array}$ \\
\hline degrees of freedom & & 4 & 3 & 3 & 2 & 1 & $1 * * * *$ \\
\hline Modelimprovement ( $p$ ) & & $<.01$ & $<.01$ & $<.01$ & $<.01$ & $<.02$ & $<.01 * * * *$ \\
\hline
\end{tabular}

* not significant (t-value $<1.96)$

* * including measurement error and sampling variance

*** as compared to model 3

$* * *$ see note 5 
In model 1, individual variables are added to the model: sex and birth order. As was expected, the latter has a negative effect on the level of secondary education achieved: the lower one's position in the birth order, the lower the educational attainment. There is no significant effect of sex: generally speaking there are no differences between boys and girls. It should be pointed out again that differences between individuals within a family can also be the result of environmental influences. Differences between brothers and sisters from the same family can relate to strictly individual characteristics, such as health, but also to specific interactions between an individual and his environment, such as with parents, peer group, or school. It would appear that this actually occurs, since a random sex effect (i.e., a sex* family interaction effect) occurs: in some families the differences between boys and girls are greater than in others.

Including both variables in the model results in a significant improvement in the model fit: the difference in $x^{2}$ between the two models is 34 (3999 - 3965) with four degrees of freedom $(p<.01)$. Both variables together account for $6 \%$ of the variance at the individual level and for $5 \%$ of the variance at the family level. This is an initial indication that the birth order effect is partly related to a family characteristic such as the number of children, as we will see in more detail below.

Model 2 includes social status variables. The standardized effects of the educational attainment of the father and of the mother are virtually the same: .26 and .22 respectively, which is twice as high as the effect of the father's occupational prestige. This is a confirmation of the stronger predictive value of educational characteristics compared to occupational characteristics. The unstandardized effects show what difference the educational attainment of a parent makes. The scale for educational attainment runs from 1 to 6 . A child whose father has completed a university education (level 6 on the educational attainment scale), chooses a school type that is on average one level higher than the one reached by a child whose father has only had primary education (level 1 on the educational attainment scale). When both parents have completed university education, the difference is two levels.

An attempt has been made to explain the random sex effect by including interaction terms of sex with one of the three status variables. It could be that in the higher status groups the girls do better and in the lower status groups the boys do better. These interaction terms, however, do not prove significant. In other words, families differ in the degree to which sex has an effect on educational attainment, but these differences cannot be traced back to status differences.

The inclusion of status variables results in a substantial increase of the model fit: $x^{2}=230$ with three degrees of freedom. The variables in the model now account for $7 \%$ of the variance at the individual level, $50 \%$ of the variance at family level, whereas all variance at the neighbourhood level is sufficiently 'explained': the remaining variance at the neighbourhood level no longer deviates significantly from zero. This means that the systematic variance that originally existed between neighbourhoods can almost entirely be explained as a result of the social composition of the neighbourhood: some neighbourhoods have on average a higher 
educational attainment because the families that live there have a higher social status. This is somewhat different to the results of Garner and Raudenbush (1991). After controlling for social status variables, a systematic neighbourhood variance of about $3 \%$ remained in their analysis. This difference could be related to the fact that the neigbourhoods in the Scottish study have larger differences in social deprivation than in this Dutch study.

In model 3 the variables which show the family's access to relevant social networks are included. These are the variables of single-parent family, unemployment of the father, and the two variables related to the social participation of the mother. The latter two appear to have no significant effect in combination with the others, and were dropped from subsequent analyses. The variable one-parent family has a strong effect. Children from one-parent families choose a much lower level of secondary education: on average the difference amounts to half a point on the scale used here. The standardized effect is almost the same as that of the occupational prestige of the father. If the father has ever been jobless in the period during which the cohort was studied, this has a negative effect on his children's attainment. The effect is, however, not as strong as that of one-parent family. As expected, the introduction of the variable 'number of children' causes a slight drop in the birth order effect (from .09 to .06 , but still significant). The effect of the number of children in the family is equally high: .05 . One can conclude that access to relevant social networks has an important impact on the educational attainment of children. The three variables cause a significant improvement in the model fit $\left(x^{2}=30 ; \mathrm{df}=3 ; \mathrm{p}<\right.$ .01 ), while the modelled variance at family level rises from 50 to $57 \%$.

In model 4 the variables that describe the social capital of the family are introduced. One of them, occupational prestige of the grandfather, turns out to have no significant effect, and is left out of subsequent analysis. The other two variables do have the expected effects on the level of secondary education. If the social network around the family has a limited, closed character, this is disadvantageous for the children's educational attainment; a more open network has a favourable effect. Also the average occupational level of the persons belonging to the network has a positive effect on educational attainment. The standardized effects of these variables, in this model, are comparable to the effect of the father's occupational prestige. The addition of these two variables leads again to a significant improvement of the model fit $\left(x^{2}=17 ; \mathrm{df}=2 ; p<.01\right)$, while the modelled variance at the family level increases from $57 \%$ to $61 \%$.

In the following analysis (model 5) the effect of the social deprivation score of the neighbourhood is added to the model ${ }^{5}$. The inclusion of this variable does not significantly improve the model fit $\left(x^{2}=6 ; \mathrm{df}=1 ; \mathrm{p}<.02\right)$. The unstandardized effect of the factor score, however, amounts to -.10 and is also significantly smaller than zero. The standardized effect size of this variable is comparable to that of father's occupational prestige. The hypothesized

5. This appears to be redundant, since no systematic variance remains at the neighbourhood level. It is possible, however, to improve the model, since the social deprivation score of the neighbourhood may account for observed between neighbourhood variation (i.e. parameter and sampling variance, c.f. Snijders and Bosker, forthcoming). 
suppressor effects seem to be present indeed, since the effect of the social deprivation of the neighbourhood is significant but the prediction does not improve. ${ }^{6}$

In the last analysis (model 6) the network variables are deleted from the prediction model to find out whether these variables mediate to a certain extent the effect of the social deprivation of the neighbourhood. The model deteriorates: in comparison with model 5 the fit is worse $\left(x^{2}\right.$ $=14 ; \mathrm{df}=2 ; \mathrm{p}<.011$. But on the other hand, this model fits better to the data than model 3 . Evaluating the information given by model 3 to model 6 , it can be concluded that the effect of the social deprivation of a neighbourhood is indeed partly mediated by the networks that families live in. Moreover, the effect size of the social deprivation variable is greater than the effect sizes of most variables in the prediction model. Only the effect sizes of the variables educational attainment of the parents and of the single-parent family variable are larger.

To summarize the results, the main predictors of the level of the educational attainment of the children are, in the first place, the educational attainment of both parents, followed at some distance by the variables 'one-parent family', 'occupational prestige of the father', 'occupational level of acquaintances', and 'social deprivation of the neighbourhood'. The variables 'birth order', 'unemployment of the father', 'social network', 'sex', and 'number of children' have the smallest standardized effects. All of these variables together explain $6 \%$ of the variance that was originally at individual level, $61 \%$ of the variance that was originally at family level, and $100 \%$ of the neighbourhood variance.

Since the neighbourhood variation must be partly reattributed to differences between the families who live in a neighbourhood, one could combine the family and neighbourhood components of the variance. This brings the environmental variance to $48 \%(35+13)$. The variables from model 5 could be said to explain $72 \%$ of this environmental effect $161 * 35 \%+$ $100 * 13 \%) / 48 \%=72 \%$. This environmental variance, which thus consists mainly of family variance, is for $59 \%$ determined by the social status of the parents. The social resources available to a family contribute another $5 \%$ of the variance, the most important factors being access to social networks and the social status of the network or neighbourhood. The standardized effect of the various social resources are comparable to the standardized effect of the occupational prestige of the father. Moreover, we have succeeded in finding an explanation why children from families living in social deprived neighbourhoods have less educational opportunities than children from families living in priviliged areas: their families are more likely to have a narrow ranged, low status network.

6. Applying a two-level analysis (families and neigbourhoods only) shows: the social deprivation score of the neighbourhood accounts for $91 \%$ of the variation between neighbourhoods in the occupational prestige of the acquaintances. Applying a two-level logistic analysis results in the finding, that the deprivation factor accounts for $98 \%$ of the between neighbourhood variation in the extensiveness of the network of the families. 


\section{CONCLUSION}

This article has attempted to answer two questions: what is the total effect of the family and the social environment on the educational attainment of children, and what is the role in this of social resources? The determination of the total influence of the family and its surrounds requires that the total variance in educational attainment must be broken down into variance within families, variance between families and variance between neighbourhoods. Using a multilevel statistical model, three levels were distinguished: the children from a single family, the family itself, and the neighbourhood in which the family lives. Several variables were adopted in the analysis, for each of these three levels.

About half of the variance in educational attainment can be attributed to systematic environmental differences, mainly consisting of differences between families. Differences in average educational attainment between neighbourhoods are very small, after controlling for differences in the social status of the families. The environmental influence reflects both the common genetic inheritance, shared child-rearing characteristics, and the mutual influence of brothers and sisters, as well as the common influence of the social network surrounding the family. The remaining variance relates to the differences in the educational attainment of the children of one family. This is related to the strictly individual characteristics of the children, such as health and personality, but also to influences from the family and its surroundings which are not common to all the children within the family, such as the child's relationship with parents, teachers, and peer group. It turned out that in some families boys attain more in education than their sisters, whereas in other families the opposite is true. This supports the idea that family influences on children may also differ between children within one family.

The systematic environmental variance is to a large extent $(59 \%)$ determined by the social status of the parents. Consideration of other socio-structural characteristics of the family, such as access to and the status of the social network raises this percentage to $71 \%$. That makes it possible to form a nuanced picture of the social inequality of educational opportunity. If one considers individual students, the level of educational attainment is approximately one quarter determined by social status of the parents. Social status is therefore an important factor, but certainly is not entirely determinative. In so far as there are systematic differences between families in educational opportunities, however, it would seem that these are largely attributable to socio-structural differences. In other words, social status is the most important background to systematic differences in educational opportunity.

Furthermore, differences between families appear to be partly explained by differences in the social resources. The variables relating to access to relevant social networks (unemployment of the father, one-parent family) and those which describe the network itself (openness, social status of members, deprivation score of the neighbourhood) are all important. The standardized effects of these variables are comparable in strength to the effect of the occupational prestige of the father. Unemployment of the father or living in a one-parent family reduce access to the relevant social networks and have a negative effect on educational attainment. Where the social 
$-17-$

network of a family is very closed and limited to the immediate family, that also has a negative effect. There is also a damaging effect on educational attainment where the social status of those with whom the parents interact most closely is low.

The area in which children grow up, also contributes to educational inequality. At the very least there is some evidence for a general neighbourhood effect, although it is not quite clear whether we should attribute this effect to the direct environment of the family (the networks in which they participate) or the wider environment of the neighbourhood as a whole. Neighbourhoods seem to produce different opportunity structures by making different amounts of social capital available. One could also interpret this finding as reflecting the limited understanding that low status families offer their children through their networks of the importance of education. 


\section{REFERENCES}

Aitkin, M., and N.T. Longford. 1986. "Statistical Modelling Issues in School Effectiveness Studies." The Journal of the Royal Statistical Society, Series A (General), 149, Part 1:1-43.

Bakker, B.F.M., and S.P. Schouten. 1991. "Trends in Onderwijskansen. Een Vergelijking van de Overgang naar het Voortgezet Onderwijs van de Generaties Geboren rond 1953, 1965 en 1971." Sociale Wetenschappen 34:1-21.

Benin, M.H., and D.R. Johnson. 1984. "Sibling Similarities in Educational Attainment: A Comparison of Like- Sex and Cross-Sex Sibling Pairs." Sociology of Education 57: 11-21.

Bosker, R.J., W.H.A. Hofman, and R.K.W. Van der Velden. 1985. Een Generatie Geselecteerd. Deel 1: De Loopbanen. Groningen: RION.

Bosker, R.J., and R.K.W. Van der Velden, and L. Otten. 1989. “Social Stratification and Educational Career." Pp. 99- 120 in Similar or Different? Continuities in Dutch Research on Social Stratification and Social Mobility, edited by W. Jansen, J. Dronkers and K. Verrips. Amsterdam: SISWO.

Bosker, R.J., and R.K.W. Van der Velden. 1989. "Schooleffects on Educational Perspectives." Pp. 131-150 in Educational Opportunities in the Welfare State. Longitudinal Studies in Educational and Occupational Attainment in the Netherlands, edited by B.F.M. Bakker, J. Dronkers and W.G. Meijnen. Nijmegen: ITS.

Bosman, R. and W. Louwes. 1988. "Een Ouder- en Twee Oudergezinnen en Schoolloopbanen." Mens en Maatschappij 63:5-23.

Bosman, R. and W. Louwes. 1989. Gezinssituaties en Onderwijskansen. Een Toetsing van Verklaringen voor de Schoolloopbaanverschillen tussen Kinderen uit Een- Oudergezinnen en Twee-Oudergezinnen. Nijmegen: ITS/OoMO.

Bourdieu, P. 1984. Distinction, a Social Critique of the Judgement of Taste. London: Routledge and Kegan Paul.

Centraal Bureau voor de Statistiek. 1981. 14e Algemene Volkstelling Annex Woningtelling. 28 februari 1971. Deel 1a: Plaatselijke Indeling Bevolking van Gemeenten en Onderdelen van Gemeenten. Den Haag: Staatsuitgeverij.

Collins, R. 1979. The Credential Society. New York: Academic Press.

De Graaf, N.D. and H.D. Flap. 1988. "With a Little Help from My Friends." Social Forces 67:452-472. 
De Graaf, P.M. 1986. "The Impact of Financial and Cultural Resources on Educational Attainment in the Netherlands." Sociology of Education 59:237-246.

De Graaf, P.M., and J.J. Huinink. 1991. "Trends in Measured and Unmeasured Effects of Family Background on Educational Attainment and Occupational Achievement in the Federal Republic of Germany." Social Science Research (forthcoming).

De Graaf, P.M. 1989. "Cultural Reproduction and Educational Stratification." Pp. 39-58 in Educational Opportunities in the Welfare State. Longitudinal Studies in Educational and Occupational Attainment in the Netherlands, edited by B.F.M. Bakker, J. Dronkers and W.G. Meijnen. Nijmegen: ITS.

Districtsbureau Arbeidsvoorziening Groningen. 1983. Indeling naar Werksoorten en Ambachten (ARBIWA). Groningen.

Doeringer, P.B., and M.J. Piore. 1971. Internal Labor Markets and Manpower Analysis. Lexington, Mass: D.C. Heath, Lexington Books.

Dronkers, J., and E. Diekerhof. 1984. "The Effects of District Participation in Different Types of Secondary Education on the Educational Careers of Individuals." Pp. 82-97 in Multi-level Aspects in the Educational Process, edited by P. van den Eeden and H. Oosthoek. London: Gordon and Beach.

Dronkers, J., and B. Schijf. 1986. “Neighbourhoods, Schools, and Individual Attainment: a Better Model for Analyzing Unequal Educational Opportunities." Pp. 203-225 in Research in Sociology of Education and Socialization, 6. International Perspectives on Education, edited by A.C. Kerckhoff. Greenwich CT: JAI-Press.

Dronkers, J. 1989. "The Power of the Family." Pp. 121-136 in Similar or Different? Continuities in Dutch Research on Social Stratification and Social Mobility, edited by W. Jansen, J. Dronkers and K. Verrips. Amsterdam: SISWO.

Dronkers, J. 1990. “The Yield of Dutch Educational Attainment Research; a Retrospective View of the Last Decennium." Pp. 1-20 in Educational Opportunities in the Welfare State. Longitudinal Studies in Educational and Occupational Attainment in the Netherlands, edited by B.F.M. Bakker, J. Dronkers and W.G. Meijnen. Nijmegen: ITS.

Ganzeboom, H.B.G. 1988. Leefstijlen in Nederland: een Verkennende Studie. Rijswijk: Sociaal en Cultureel Planbureau.

Garner, C.L., and S.W. Raudenbush. 1989. Neighbourhood Effects on Educational Attainment: a Multi-level Analysis. Paper ESRC. Edinburgh/Michigan. 
Goldstein, H. 1987. Multi-level Models in Educational and Social Research. Londen: Charles Griffin and Co.

Granovetter, M.S. 1973. "The Strength of Weak Ties." American Journal of Sociology 78:1360-1380.

Hallinan, M.T. 1988. "Equality of Educational Opportunity." Annual Review of Sociology 14:249-268.

Hauser, R.M. 1970. "Context and Consex. A Cautionary Tale." American Journal of Sociology 75:645-664.

Hauser, R.M., and W.H. Sewell. 1985. "Birth Order and Educational Attainment in Full Sibships." American Educational Research Journal 22:1-23.

Hauser, R.M., and P.A. Mossel. 1985. "Fraternal Resemblance in Educational attainment and Occuptaional Status." American Journal of Sociology 91:650-73.

Hauser, R.M., and W.H. Sewell. 1986. "Family Effects in Simple Models of Educationan, Occupational Status, and Earnings: Findings from the Wisconsin and Kalamazoo Studies." Journal of Labor Economics 4:83:115.

Hauser, R.M., and R.S.K. Wong. 1989. "Sibling Resemblance and Inter-Sibling Effects in Educational Attainment." Sociology of Education 62:149-171.

Huckfeldt, R.R. 1983. "Social Contexts, Social Networks, and Urban Neighborhoods: Environmental Constraints on Friendship Choice." American Journal of Sociology 3:651-669.

Hummel, H.J. 1972. Probleme der Mehrebenen Analyse. Stuttgart: Teulner.

Lin, N., W.M. Ensel, and J.C. Vaughn. 1981. "Social Resources and the Strength of Ties: Structural Factors in Occupational Status Attainment." American Sociological Review 46:393405.

Longford, N.T. 1986. Variance Component Analysis: Manual. Lancaster: University of Lancaster.

Meijnen, W.G. 1977. Maatschappelijke Achtergronden van Intellectuele Ontwikkeling. Groningen: Wolters-Noordhoff.

Meijnen, W.G. 1984. Van Zes tot Twaalf. Harlingen: Flevo-druk.

Neidhardt, F. 1970. “Strukturbedingungen und Probleme familialer Sozialisation." Pp. 144-168 
in Soziologie der Familie. Sonderheft 14 der Kölner Zeitschrift für Soziologie und Sozialpsychologie, edited by G. Lüschen and E. Lupri. Opladen: Westdeutscher Verlag.

Olneck, M.R. 1977. "On the Use of Sibling Data to Estimate the Effects of Family Background, Cognitive Skills, and Schooling: Results from the Kalamazoo Brothers Study." Pp. 125-162 in Kinometrics: Determinants of Socioeconomic Success Within and Between Families, edited by P. Taubman. Amsterdam: North Holland Publishing Co.

Raudenbush, S.W., and A.S. Bryk. 1986. "A Hierarchical Model for Studying Schooleffects." Sociology of Education 59:1-17.

SCP. 1980. Sociale Achterstand in Wijken en Gemeenten. Rangorde van Nederlandse Wijken en Gemeenten naar Sociale Achterstand op Basis van de Algemene Volkstelling 1971. SCP-cahier no. 14. Rijswijk: Sociaal en Cultureel Planbureau.

Snijders, T.A.B. and R.J. Bosker. Forthcoming. Modeled variance in two-level models.

Tazelaar, F. and M. Springers. 1984. “Werkloosheid en Sociaal Isolement." Sociologische Gids 31:48-79.

Te Grotenhuis, H. and J. Dronkers. 1989. "Enkele Gevolgen van Werkloosheid en Arbeidsongeschiktheid in de Verzorgingsstaat; Ongelijke Onderwijskansen van Kinderen." Amsterdams Sociologisch Tijdschrift 15:634-651.

Van Westerlaak, J.M., J.A. Kropman, and J.W.M. Collaris. 1975. Beroepenklapper. Nijmegen: ITS.

Wilson, W.J. (1991). 'Studying Inner-City Social Dislocations'. American Sociological Review 56: 1-14.

Zajonc, R.B., and G.B. Markus. (1975). "Birth Order and Intellectual Development." Psychological Review 82:74-88. 


\section{APPENDIX. DESCRIPTION OF VARIABLES}

1. Level of secondary education: choice of secondary education of the children from a family (transformed).

code: 1 = IBO (individual primary education), BUO (special education), primary education

$2=$ LBO (lower vocational education), KMBO (short intermediate vocational education)

3 = MAVO (lower general secondary education), 2-year MBO (intermediate vocational education)

4 = HAVO (higher general secondary education), 3-year MBO

5 = VWO (pre-university education), HBO (higher vocational education), university

$\mathrm{x}=3.3 \quad \mathrm{sd}=1.2 \quad \mathrm{n}=1357$

2. Birth order: position of the child in the birth order

Range: 1 - 12

$x=2.2 \quad s d=1.4 \quad n=1357$

3. Sex: sex of the children in the family

code: $0=$ boy

$1=$ girl

$\mathrm{x}=.51 \quad \mathrm{sd}=.50 \quad \mathrm{n}=1357$

4. Education father: educational attainment of the father

code: 1 . only primary education

2. lower vocational education, not completed

3. lower vocational education with certificate or a few years general education

4. extended primary education with certificate or three or more years lower or higher general secondary education

5. lower or higher general secondary education with certificate; intermediate vocational education with certificate or a few years higher vocational education

6. higher vocational education with certificate or university education

$x=3.4 \quad s d=1.5 \quad n=519$

5. Education mother: idem

$\mathrm{x}=3.0 \quad \mathrm{sd}=1.3 \quad \mathrm{n}=519$ 
6. Occupation father: occupational prestige of the father according to the ITS-occupation guide (Van Westerlaak, Kropman and Collaris 1975).

code: 1 . unskilled labour

2. skilled labour

3. non-manual labour

4. self-employed

5. salaried staff

6. higher professions

$\mathrm{x}=3.3 \quad \mathrm{sd}=1.5 \quad \mathrm{n}=519$

7. Number of children: number of children in the family

Range: 1-12

$\mathrm{x}=2.8 \quad \mathrm{sd}=1.3 \quad \mathrm{n}=519$

8. One-parent family: divorce or decease of one of the parents

code: $0=$ both parents present

$1=$ parent(s) divorced or deceased

$\mathrm{x}=.17 \quad \mathrm{sd}=.38 \quad \mathrm{n}=519$

9. Working father: has the father been unemployed or declared incapacitated at any time between 1972 and 1984 ?

code: $0=$ yes

$1=$ no

$x=.78 \quad s d=.42 \quad n=453$

(N.B.: in the case of missing observations - mostly because there is no father - code 1 has been assigned).

10. Network: whom do the parents contact?

code: $0=$ limited (relatives and/or neighbours only)

$1=$ extensive (also others)

$x=.75 \quad s d=.43 \quad n=519$

11. Occupation grandfather: occupational prestige of the grandfather on mother's side according to the ITS occupation guide (see above)

$x=3.0 \quad s d=1.5 \quad n=519$ 
12. Occupation acquaintances: average occupational level of the three most important acquaintances of the parents, according to ARBVO-level (DBA-Groningen 1975).

Range: 1 (unskilled) - 7 (academic)

$x=4.3 \quad s d=1.5 \quad n=506$

13. Diversity soc. part.: Diversity of social participation of the mother Range: 0 (no organizations) - 4 (4 different types of organizations).

$\mathrm{x}=.5 \quad \mathrm{sd}=.7 \quad \mathrm{n}=519$

14. Intensity soc. part.: how actively is the mother involved in these organizations?

Range: 12 (not actively) - 26 (very actively)

$\mathrm{x}=16.6$ sd $=15.1 \mathrm{n}=519$

15. Soc. disadvantage: factor score of the social disadvantage of the neighbourhood the family lives in, taken from SCP (1980)

Range: from - 3.28 (little disadvantage) to +1.86 (strong disadvantage)

$x=-.32 \mathrm{sd}=1.03 \mathrm{n}=42$ 